Maulana, The student of Sriwijaya University, Palembang Indonesia

e-mail: ylelmou@gmail.com

Taufiq Marwa, The Lecturer of Sriwijaya University, Palembang, Indonesia

Tertiarto Wahyudi, The Lecturer of Sriwijaya University, Palembang, Indonesia

\title{
The Effect of Transfer Pricing, Capital Intensity and Financial Distress on Tax Avoidance with Firm Size as Moderating Variables
}

\begin{abstract}
Introduction. Tax avoidance is strategies and techniques that take advantage of grey areas contained in the tax law itself. The different interests between business people and the tax office make tax avoidance a common practice. The data used in this study is secondary data from Indonesia Stock Exchange. The population of this research is 41 mining companies which are listed in Indonesian Stock Exchanges in during period 2013-2017. The number of companies that will be used for the sample in this study is 16 companies. The analytical tool used in this study is multiple regression analysis with moderating variables

Purpose. The purpose of the article is to investigate and get empirical evidence about the effect of transfer pricing, financial distress, and capital intensity on the tax avoidance with firm size as a moderator variable.

Results. The results showed that transfer pricing significantly affected tax avoidance, positive influence, financial distress significantly affected tax avoidance, negative influence, while capital intensity did not significantly affect tax avoidance, and firm size did not moderate the relationship between transfer pricing, financial distress, and capital intensity on tax avoidance

Conclution. Financial distress and transfer pricing are variables that must be considered because they show a significant influence on tax avoidance, especially transfer pricing, government regulations related to transfer pricing have proven effective in combating tax avoidance.
\end{abstract}

Keywords: Transfer Pricing; Capital Intensity; Financial Distress; Firm Size; Tax Avoidance.

удк 336.221

Маулана, студент, Університет Шривіджая, Палембанг, Індонезія

Тауфік Марва, лектор, Університет Шривіджая, Палембанг, Індонезія

Тертіарто Вах'юді, лектор, Університет Шривіджая, Палембанг, Індонезія

\section{Вплив ціноутворення, інтенсивності використання капіталу та фінансових труднощів на процеси ухилення від сплати податків}

\begin{abstract}
Анотація. У процесі ухилення від сплати податків застосовують стратегії та методи, що базуються на недосконалостях податкового законодавства. Протилежні інтереси між бізнес-структурами та податковою службою перетворили «ухилення від сплати податків» на звичайну практику. Дані, представлені в цьому дослідженні, є вторинними даними Індонезійської фондової біржі. Матеріал цього дослідження складається з 41 гірничодобувної компанї̈, що представлені на індонезійських фондових біржах протягом 2013-2017 років. Метою дослідження є отримання емпіричних доказів про наявність впливу ціноутворення, фінансових труднощів та інтенсивності використання капіталу на процеси ухилення від сплати податків. Результати показали, що трансфертне ціноутворення значно вплинуло на процеси ухилення від сплати податків, відповідно, фінансове становище суб'єкта господарювання суттєво впливає на процеси ухилення від сплати податків, тоді як інтенсивність використання капіталу впливає на процеси ухилення від сплати податків несуттєво. Фінансові проблеми суб'єкта господарювання та зміни ціноутворення є змінними, це слід враховувати, оскільки вони мають значний вплив на процеси ухилення від сплати податків, особливо це стосується змін ціноутворення, відповідно, зміни ціноутворення доцільно розглядати як ефективний інструмент у боротьбі з ухиленням від сплати податків.
\end{abstract}

Ключові слова: зміни ціноутворення; інтенсивність використання капіталу; фінансові труднощі; розмір фірми; ухилення від сплати податків.

Problem statement. Tax avoidance is strategies and techniques that take advantage of grey areas contained in

the tax law itself. Publication of panama papers open up horizons of Indonesian citizens about how the rich and big

Стаття надійшла до редакції: 25.10.2018

Received: 25 October 2018 
company's world save money in certain countries in order to avoid taxation (tax avoidance).

This study uses a positive accounting theory to explain The Effect of Transfer Pricing, Capital Intensity and Financial Distress on Tax Avoidance with Firm Size as Moderating Variables. Positive accounting theory by Watts and Zimmerman (Shil, 2014) in (Shil, 2014) trying to explain the phenomenon of accounting based on the reasons that led to the occurrence of an event.

Analysis of recent research and publications. Different interests between business people and tax offices in various countries make transfer pricing issues not easy to solve. Multinational companies tend to shift tax obligations from countries that have tax rates to countries that apply low tax rates. The company who are experiencing financial difficulties, then the manager of the company can be aggressively pursuing tax avoidance and ignoring the risk of audits conducted by the tax authorities. According to Richardson et al. (2014). There are several implications on company tax rules when the company is experiencing financial difficulties. For example, the rising cost of capital and the crisis of external financial resources (loans / loans) faced by the company and in general, the desire of managers to take risks that can restore the balance of the company through tax avoidance.

Another factor that influences tax avoidance is the condition of the company. The characteristics of the company determine the effective level of tax directly, namely capital intensity or capital ratio. Capital ratio is the number of assets that invest assets in fixed assets. According to Rodriguez and Arias in Ardyansah (2014) fixed assets that allow companies to change taxes due to depreciation expense on these assets. Fixed assets will increase depreciation and will be depreciation costs in the company's financial statements. Depreciation is costs that can be deducted from the tax calculation. The greater the depreciation cost, the smaller the tax rate is issued by the company. Companies with a large ratio level show effective tax rates, this shows the relationship between capital intensity and tax avoidance by companies.

In addition to the influence of transfer pricing and capital intensity, tax avoidance behavior is not limited by the size of a corporate entity. The Company is a taxpayer, so the size of the companies considered capable of affecting the way a company to meet its tax obligations and is a factor that can lead to tax avoidance (Dewinta \& Setiawan, 2016), Large companies in the spotlight that the government will consider in managing their tax risk, the enterprise managers are likely to be aggressive or submissive in reporting taxation (Kurniasih \& Sari, 2013).

The difference between the results of research or research between variables that affect corporate tax avoidance and some phenomena of tax avoidance cases in Indonesia, especially in the mining sector, have motivated the author to continue the research conducted by Dharma \& Ardiana (2016) by adding financial distress and pricing as independent variable and firm size as a moderating variable. The author uses the size of the company as a moderating variable because the results of testing the firm size variables in the previous research are more consistent than other research variables.

Based on the background description of the problem and several previous studies and still in accordance with the suggestions of previous studies which stated that there is still a lack of research instruments to examine tax avoidance. Have encouraged the author to compile a study entitled "The Effect of Transfer Pricing, Capital Intensity and Financial Distress on Tax Avoidance with Firm Size as Moderating Variables".

Formulation of study objectives. Transfer pricing is an issue in international transactions. In terms of government, transfer pricing results in reduced or lost potential revenue of a country, especially from taxes, because multinational companies tend to shift their tax obligations from high tax countries to low tax countries. Chronically, this problem cannot be resolved unilaterally by each country but must be carried out jointly (multilateral cooperation) but from the business side, companies tend to try to minimize costs (cost efficiency) including corporate income tax. For global scale companies such as multinational corporations, transfer pricing is one of the effective strategies to win competition in fighting over resources.

Transfer pricing is calculated using a dichotomy approach, namely by looking at the existence of transactions to related parties. The company conducts transactions with related parties given a value of 1 and is not given a value of 0 .

H1: Transfer Pricing significantly affects tax avoidance.

Capital Intensity is an investment activity in the form of fixed assets (capital). Capital intensity can reflect the amount of capital needed to generate income, so capital intensity can be an indicator of companies in fighting over the market. In this study using the fixed asset intensity ratio. Capital intensity Ratio is how much the proportion of fixed assets in the total assets owned. The increase in the company's fixed assets will increase the company's productivity and increase the company's income. High ownership of fixed assets will result in a high depreciation expense, so that the corporate tax burden will decrease. Thus, the high number of assets owned by the company encourages companies to take tax avoidance measures.

$\mathrm{H} 2$ : Capital Intensity significantly affects tax avoidance.

Companies that increase capital costs and reduced external financial resources or experience financial distress, can tend to distort the state of the company at the risk of tax avoidance practices (Richardson et al., 2014), Companies experiencing financial distress would risk more aggressive in tax avoidance to keep her company. The cash critical condition and the corporate tax burden the main thing in a cash outflow, then the company would rule out the possibility of a negative reputation gained for aggressively pursuing tax evasion. 
H3: Financial Distress significantly affects tax avoidance.

Tax avoidance practices in Indonesia involve numerous relatively large multinational companies. Several major cases of tax evasion have been taken by the Directorate General of Taxes (DGT), including cases of agriculture and mining company. This fact shows the aggressive relationship between tax avoidance and multinational companies, most of which have large firm value (Rusydi, 2013). The fact that there is an aggressive tax avoidance relationship with firm size has also been carried out by research (Richardson et al. 2014) with a political cost theory shows a positive relationship between firm size and tax avoidance.

H4: Company Size moderates the effect of transfer pricing, capital intensity and financial distress on corporate tax avoidance.

Presentation of the main research material. All mining companies listed on the Indonesia Stock Exchange are the population of this study. Sample criteria in this study are:

1. The company must be listed on the IDX and publish financial statements consistently and completely from 2013-2017.

2. Having complete information needed in relation to calculation indicators used as variables in this study.

3. Mining companies that do not have a negative tax burden.

The total of mining companies listed on the IDX are 41 companies, and those that meet the observation criteria are 16 companies. The observation period is 5 years so that the total sample in this study is 80 observations.

The study consists of one dependent, three independent variables and one moderating variable. Below is information about the variables used:

1. Tax Avoidance becomes a dependent variable that is measured by the Effective Tax Rate

2. Transfer Pricing becomes an independent variable that is measured by a dummy variable category 1 for companies that conduct related party transactions in accordance with the provisions in Indonesia and 0 for those who do not conduct related party transactions

3. Capital intensity becomes independent variable measured by capital intensity ratio

4. Financial Distress becomes an independent variable that is measured by a dummy variable, category 1 for companies that have Interest Coverage Ratio values below 1 and 0 for companies that have Interest Coverage Ratio values above 1

5 . The size of the company becomes a moderating variable as measured by the total asset logarithm.

This study uses panel data and ordinary least square models through the following regression equation

$$
\mathrm{TAXAV}=\alpha+\beta 1 \mathrm{TF}+\beta 2 \mathrm{Cl}+\beta 3 \mathrm{FD}+\mathrm{e}
$$

This study uses the OLS model so that it must pass the classic assumption test consisting of multicollinearity tests, heteroscedasticity tests and autocorrelation tests.

This study also measured the ability of the company size variable in moderating the relationship between the effects of transfer pricing, capital intensity and financial distress on corporate tax avoidance by using the residual test as follows:

$$
\begin{gathered}
\mathrm{FS}=\alpha+\beta 1 \mathrm{TF}+\beta 2 \mathrm{Cl}+\beta 3 \mathrm{FD}+\mathrm{e} \\
\{\mathrm{e}\}=\alpha+\beta 4 \mathrm{TAX} \text { AV }
\end{gathered}
$$

Descriptive statistics are statistics that function to describe or give an overview of the object of research through sample data or population as they are, without analysing and making generally accepted conclusions (Sugiyono, 2013).

Table 1 Results of Descriptive Statistics

\begin{tabular}{|c|c|c|c|c|c|}
\hline & N & Min & Max & Mean & Std. deviation \\
\hline Tax Avoidance (ETR) & 80 & -0.43 & 0.92 & 0.2817 & 0.20618 \\
\hline Transfer Pricing & 80 & 0.00 & 1.00 & 0.7625 & 0.42824 \\
\hline Capital Intensity & 80 & 0.00 & $0: 51$ & 0.2472 & 0.13695 \\
\hline Financial Distress & 80 & 0.00 & 1.00 & 0.1375 & 0.34655 \\
\hline Company size & 80 & 11.20 & 13.97 & 12.6685 & 0.65925 \\
\hline Valid N (listwise) & 80 & & & & \\
\hline
\end{tabular}

Source: modified output of SPSS

Results from the classical assumption test using statistical testing tools can be seen as follows:

1. Multicollinearity
Multicollinearity test results with SPSS tools show the following values 
Table 2 Multicollinearity Test

\begin{tabular}{|c|c|}
\hline Variable & VIF \\
\hline TF & 1.268 \\
\hline FD & 1.525 \\
\hline $\mathrm{Cl}$ & 1.251 \\
\hline
\end{tabular}

Source: modified output of SPSS 21

Based on the results of the regression equation table 2 , it can be seen that all variables have a VIF value smaller than 10 , it can be concluded that regression model does not have multicollinearity problems.

\section{Heteroscedasticity}

Heteroscedasticity test with SPSS tools to demonstrate the value as follows

Table 3 Heteroscedasticity Test

\begin{tabular}{|c|c|}
\hline Variable & Sig. \\
\hline $\mathrm{TF}$ & 0.186 \\
\hline $\mathrm{FD}$ & 0.212 \\
\hline $\mathrm{Cl}$ & 0.644 \\
\hline
\end{tabular}

Source: modified output of SPSS

Significant value more than 0.05 so that it can be concluded that the model is free from heteroscedasticity

3. Autocorrelation

Autocorrelation test with SPSS tool shows the Durbin Watson value is 2.136 , and the DU value is 1.7430 so that the Durbin Watson value is between the DU and 4-DU values, then the regression model is free from autocorrelation

After the classical assumption, we will test regression models with SPSS 20, following the results of the regression test with SPSS:

Table 4 Results of regression Test Estimation Model

\begin{tabular}{|c|c|c|c|c|}
\hline Variables & coefficients & Std.Error & $T$ & Sig. \\
\hline & 0.235 & 0.065 & 3.609 & 0.001 \\
\hline TF & 0.149 & 0.051 & 2.900 & 0.005 \\
\hline Cl & -0.141 & 0.159 & -0.882 & 0.381 \\
\hline FD & -0.229 & 0.07 & -3.292 & 0.002 \\
\hline
\end{tabular}

Source: modified output of SPSS

Table 5 Residual Test Results

\begin{tabular}{|c|c|c|c|c|}
\hline \multirow{2}{*}{ variables } & \multicolumn{2}{|c|}{ Coefficients } & $T$ & Sig. \\
\hline & 0.418 & 0.057 & 7.342 & 0 \\
\hline Tax Av & 0.122 & 0.164 & 0.748 & 0.457 \\
\hline
\end{tabular}

Source: modified output of SPSS

Statistical testing in this study was carried out by comparing the significance value of each variable, if the significance value is less than $5 \%$ then the hypothesis is accepted and if more than $5 \%$ the hypothesis is rejected.
Transfer pricing significantly affects tax avoidance, positive effect because the significance value is 0.005 less than 0.05 . Capital intensity doesn't significantly affects tax avoidance because the significance value is 0.381 greater than 0.05 . Financial distress significantly affects tax 
avoidance, negative effect because the significance value is 0.002 smaller than 0.05 . The last hypothesis, Company size variable doesn't moderate the relationship between transfer pricing, capital intensity and financial distress to tax avoidance because the coefficient shows a positive value of 0.122 and its significance is 0.457 greater than 0.05 .

In the regression equation, it can be seen that Transfer Pricing has a positive effects on ETR (The proxy of Tax Avoidance). If the effective tax rate value gets smaller then the higher the level of tax avoidance, so it can be concluded that Transfer Pricing has a negative effect on tax avoidance. This result proves that Indonesia has been quite successful in preventing tax avoidance through the transfer pricing mechanism by issuing a series of regulations that have sanctions quite heavy. For taxpayers, companies that carry out transfer pricing actions will be careful in reporting their taxes, because the risk of tax audits arising from strict regulations related to transfer pricing will be avoided by every company. This study shows results that are different from the research conducted by Handayani \& Arfan (2014). Cazacu (2017) which shows that transfer pricing has a positive effect on the practice of tax avoidance by companies.

In the regression equation can be seen that capital intensity doesn't significantly affects tax avoidance, significance value greater than 0.05 indicates that the influence of capital intensity on tax avoidance is not too significant, this is due to the low ratio of capital intensity in mining companies that become the sample of research, This is indicated by the median value obtained from a minimum value of 0.00 and a maximum value of 0.51 then divided by two showing a value of 0.255 , with a mean lower than the median, it can be concluded that the average of mining companies sector listed on the Indonesia Stock Exchange have a low ratio of capital intensity.The results of this study are inconsistent with the research conducted by Jeong Ho Kim (2017) which states that Capital Intensity has a significant positive effect on corporate tax avoidance.

In the regression equation, it can be seen that financial distress has a negative effect on ETR. If the ETR value gets smaller, the higher the level of tax avoidance, so it can be concluded that financial distress has a positive effect on tax avoidance. The results are consistent with the political cost hypothesis on positive accounting theory, the political cost hypothesis explains that companies that have large profits, tend to get a lot of attention from the government so that it will cause political costs. Like the imposition of high taxes and demands for great responsibility for the environment. To avoid, companies tend to reduce profits earned so that the political costs incurred are not too large. The results of this study are also consistent with the research from Feizi et al. (2016), which proves the positive influence of financial distress on tax avoidance
Dependent variable test results (Y) Tax avoidance of the residual absolute Moderation variable that is Company Size obtained positive coefficient value of 0.122 and significance value more than $5 \%$, it can be concluded that the firm size variable can not moderate the relationship between Transfer Pricing variables, Capital Intensity and Financial distress to tax avoidance.

In this study all companies have a natural logarithm of total assets of more than 10. The difference in the size of the company that is not too far away may affect the results of the study so that the company size research variable is not able to strengthen or weaken the tax avoidance carried out by mining companies in Indonesia. The results are consistent with the research conducted by Ginting (2016) which states that the size of the company is not able to be a moderating variable for the independent variable of the tax avoidance variable.

This study is in accordance with the implications of positive accounting theory that under certain conditions, companies will carry out the most appropriate policies to maintain their survival. This research is able to increase understanding for companies listed on the IDX on the importance of legal tax planning to avoid tax evasion that leads to unconstitutional actions. The success of the government by minimizing the negative impact of the transfer pricing action must be appreciated, but sustainable regulation must still be increased to anticipate avoidance practices or even tax evasion carried out by the company.

The government must also consider the variables of financial distress that affect the increase in tax evasion carried out by a company. Companies that are in financial difficulties will try to minimize the company's cash expenses to reduce or overcome financial problems and ignore the risk of tax audits. The government must make new regulations related to companies that continue to report losses but continue to operate, because this indicates a tax avoidance that may be intentionally carried out by the company.

Conclusions. The purpose of this study was to investigate the effect of transfer pricing, capital intensity and financial distress on tax avoidance. The results showed that transfer pricing and financial distress variables significantly affect tax avoidance, while capital intensity variables had no significant effect on corporate tax avoidance, and the firm size variable is not able to moderate the occupancy between transfer pricing, capital intensity and financial distress variables for corporate tax avoidance.

Suggestions for further researchers, in order to develop theory and expand population and cross-country research samples. Tax avoidance research should also add aspects of behaviour and culture because the perception of tax depends on how individuals perceive the tax itself, both taxes are considered as a burden or as a form of responsibility for economic development in a country. 


\section{References}

1. Annuar, H. A., Salihu, I. A., \& Obid, S. N. S. (2014). “Corporate Ownership, Governance And Tax Avoidance: An Interactive Effects", Procedia - Social and Behavioral Sciences, vol. 164, pp. 150-160. https://doi.org/10.1016/i.sbspro.2014.11.063 (Accessed 01 October 2018).

2. Anouar, D. (2017). "The Determinants of Tax Avoidance Within Corporate Groups: Evidence from Moroccan Groups". International Journal of Economics, Finance and Management Sciences, vol. 5(1), p. 57.

3. Ardyansah, D. (2014). "Pengaruh Size, Leverage, Profitability, Capital Intensity Ratio Dan Komisaris Independen Terhadap Effective Tax Rate (Etr)". Diponegoro Journal of Accounting, vol. 3, pp.1-9.

4. Ayuningsih, L. D., \& Nurcholisah, K. (2015). “Pengaruh Debt Covenant, Kepemilikan Manajerial, Dan Growth Opportunities terhadap Konservatisme Akuntansi". Ejournal Unisba, pp. 19-30.

5. Bachas, P., \& Jensen, A. (2017). "The Firm Size Gradient In Tax Policy : Global Evidence".

6. Bao, D., \& Romeo, G. C. (2013). "Tax Avoidance and Corporations in the United States - The Effective Tax Rate Abnormality For The Top Five Percent By Corporate Size". Journal of Applied Business and Economics, vol. 14(4), pp. 88-101.

7. Cazacu, A.-L. (2017). "Transfer Pricing And The Manifestations Of Tax Evasion". Journal of International Business and Economics, vol. 5(1), pp. 114-118. https://doi.org/10.15640/jibe.v5n1a10 (Accessed 01 October 2018).

8. Davies, R. B., Martin, J., Parneti, M., \& Toubal, F. (2014). “Knocking on Tax Haven's Door : Multinational Firms And Transfer Pricing".

9. Dewinta, I. A. R., \& Setiawan, P. E. (2016). “Pengaruh Ukuran Perusahaan, Umur Perusahaan, Profitabilitas, Leverage, Dan Pertumbuhan Penjualan Terhadap Tax Avoidance”. E-Jurnal Akuntansi Universitas Udayana, vol. 14(3), pp. 1584-1613.

10. Dharma, I. M. S., \& Ardiana, P. A. (2016). "Pengaruh Leverage, Intensitas Aset Tetap, Ukuran Perusahaan, dan Koneksi Politik Terhadap Tax Avoidance". E-Jurnal Akuntansi Universitas Udayana, vol. 15(1), pp. 584-613.

11. Direktorat Jendral Pajak Republik Indonesia. (2017). Peraturan Direktorat Jendral Pajak Nomor PER-31/PJ/2017 Tentang Perubahan Kedua Atas Peraturan Direktur Jenderal Pajak Nomor Per-16/Pj/2014 Tentang Tata Cara Pembuatan Dan Pelaporan Faktur Pajak Berbentuk Elektronik. Retrieved from jakata: Kementrian Keuangan Republik Indonesia.

12. Evertsson, N. (2016). "Is The Top Leadership Of The Organizations Promoting Tax Avoidance?" Journal of Financial Crime, vol. 23(2).

13. Fakhri Husein, M., \& Pambekti, G. T. (2014). "Precision Of The Models Of Altman, Springate, Zmijewski, And Grover For Predicting The Financial Distress". Journal of Economics, Business, and Accountancy Ventura, vol. 17(3), pp.405-416.

14. Feizi, M., Panahi, E., Keshavarz, F., Mirzaee, S., \& Mosavi, S. M. (2016). "The Impact Of The Financial Distress On Tax Avoidance In Listed Firms: Evidence From Tehran Stock Exchange (TSE)". International Journal of Advanced Biotechnology and Research, vol. 7(1), pp. 976-2612.

15. Fith Yuniar Ichwan, D. W. (2015). "Pengaruh Ukuran Perusahaan, Struktur Aset Dan Profitabilitas Terhadap Struktur Modal”. Jurnal Ilmu \& Riset Akuntansi, vol. 4(6), pp. 1-19.

16. Francis, B. B., Ren, N., \& Wu, Q. (2017). "Banking Deregulation And Corporate Tax Avoidance”. China Journal of Accounting Research, vol. 10(2), pp. 87-104.

17. Gaaya, S., Lakhal, N., \& Lakhal, F. (2017). “Does Family Ownership Reduce Corporate Tax Avoidance? The Moderating Effect Of Audit Quality". Managerial Auditing Journal, vol. 32(7), pp. 731-744.

18. Ghazali, I. (2013). "Aplikasi Analisis Multivariate Dengan Program SPSS Edisi Ketujuh". Semarang: Badan Penerbit Universitas Diponegoro.

19. Handayani, D., \& Arfan, T. (2014). "Pengaruh Transaksi Perusahaan Afiliasi Terhadap Tarif Pajak Efektif”. Jurnal Akuntansi Keuangan Dan Bisnis, vol. 7, pp. 11-19.

20. Irianto, B. S., Sudibyo, Y. A., \& Abim Wafirli. (2017). The Influence Of Profitability, Leverage, Firm Size And Capital Intensity Towards Tax Avoidance, vol. 5(2), pp. 33-41.

21. Jeong Ho Kim (2017). "The Study On The Effect And Determinants Of Small - And Medium-Sized Entities Conducting Tax Avoidance". The Journal of Applied Business Research, vol. 33(2), pp. 375-390.

22. Koh, Y., \& Lee, H.-A. (2015). "The Effect Of Financial Factors On Firms' Financial And Tax Reporting Decisions". Asian Review of Accounting, vol. 23(2), pp. 110-138.

23. Kubick, T. R., Lynch, D. P., \& Mayberry, M. A. (2014). The Effects of Increased Financial Statement Disclosure Quality On Tax Avoidance: An Examination of SEC Comment Letters Thomas.

24. Kurniasih, T., \& Sari, M. M. R. (2013). "Pengaruh Return on Assets, Leverage, Corporate Governance, Ukuran Perusahaan Dan Kompensasi Rugi Fiskal Pada Tax Avoidance". Buletin Studi Ekonomi, vol. 18(1), pp. 58-66.

25. Liu, L., Schmidt-Eisenlohr, T., \& Guo, D. (2017). International Transfer Pricing And Tax Avoidance: Evidence From Linked Trade-Tax Statistics in the UK.

26. Marcelliana, E., \& Purwaningsih, A. (2013). Pengaruh Tax Avoidance Terhadap Cost of Debt Pada Perusahaan Manufaktur Yang Terdaftar Di Bursa Efek Indonesia Periode 2010 - 2012, pp. 1-11.

27. Mardiasmo (2014). Perpajakan. Yogyakarta: Andi Offset.

28. Meilia, P., Keuangan, M., Indonesia, R., \& Indrawati, M. (2017). "Pengaruh Financial Distress, Karakteristik Eksekutif, Dan Kompensasi Eksekutif Terhadap Tax Avoidance". Jurnal IImiah Mahasiswa Ekonomi Akuntansi (JIMEKA), vol. 2(4), pp. 84-92.

29. Menteri Keuangan Republik Indonesia. (2012). Peraturan Menteri Keuangan Republik Indonesia Nomor 136/PMK. 03/2012 Tentang Perubahan Atas Peraturan Menteri Keuangan Nomor 85/Pmk.03/2012 Tentang Penunjukan Badan Usaha Milik Negara Untuk Memungut, Menyetor, Dan Melaporkan Pajak Pertambahan Nilai. Retrieved from jakata: Kementrian Keuangan Republik Indonesia. 
30. Menteri Keuangan Republik Indonesia. (2016). Peraturan Menteri Keuangan Republik Indonesia Nomor 213 / Pmk. 03/ 2016 Tentang Jenis Dokumen Dan Atau Informasi Tambahan Yang Wajib Disimpan O Leh Wajib Pajak Yang Melakukan Transaksi Dengan Para Pihak Yang Mempunyai Hubungan Istimewa. Retrieved from jakata: Kementerian Keuangan Republik Indonesia.

31. Nawangwulan Maya (2014). Modus Skandal Pajak Perusahaan Sawit dan Tambang.

32. Novari, P. M. (2016). “Pengaruh Ukuran Perusahaan, Leverage, Dan Profitabilitas Terhadap Nilai Perusahaan Pada Sektor Properti Dan Real Estate”. E-Jurnal Manajemen Unud, vol. 5(9), pp. 5671-5694.

33. Nugraha, M. (2015). "Pengaruh Corporate Social Responsibility, Ukuran Perusahaan, Profitabilitas, Leverage Dan Capital Intensity Terhadap Agresivitas Pajak". Diponegoro Journal of Accounting, vol. 4, pp. 1-14.

34. Nugroho, S. A., \& Firmansyah, A. (2017). "Pengaruh Financial Distress, Real Earnings Management, dan Corporate Governance terhadap Tax Aggressiveness". Journal of Business Administration, vol. 1(2), pp. 17-36.

35. Nurfadilah, Mulyati, H., Purnamasari, M., \& Niar, H. (2015). Pengaruh Leverage, Ukuran Perusahaan, dan Kualitas Audit Terhadap Penghindaran Pajak. Seminar Nasional Dan The 3rd Call for Syariah Paper, pp. 441-449.

36. Nurjanah, M., Diatmika, I. P. G., \& Yasa, I. N. P. (2017). “Pengaruh Profitabilitas, Capital Intensity Ratio, Size, Dan Leverage Perusahaan Pada Manajemen Pajak". E-Journal Ak Universitas Pendidikan Ganesha, vol. 1(2)

37. Pohan, C. A. (2017). Manajemen Perpajakan. Jakarta: PT Gramedia Pustaka Utama.

38. Putra, R. R. R., Handayani, S. R., \& Topowijono (2014). “Pengaruh Sanksi Administrasi Sosialisasi Perpajakan Dan Kesadaran Wajib Pajak Terhadap Kepatuhan Penyampaian SPT Tahunan Wajib Pajak Orang Pribadi”. Jurnal E-Perpajakan, vol. 1(1).

39. Richardson, G., Lanis, R., \& Taylor, G. (2014). "Financial Distress, Outside Directors And Corporate Tax Aggressiveness Spanning The Global Financial Crisis: An Empirical Analysis". Journal of Banking and Finance, vol. 52, pp. 112-129.

40. Richardson, G., Taylor, G., \& Lanis, R. (2015). "The Impact Of Financial Distress On Corporate Tax Avoidance Spanning The Global Financial Crisis: Evidence From Australia". Economic Modelling, vol. 44, pp. 44-53.

41. Rusydi, M. K. (2013). "Pengaruh Ukuran Perusahaan Terhadap Aggressive Tax Avoidance Di Indonesia”. Jurnal Akuntansi Multiparadigma, vol. 4(2), pp. 322-329.

42. Salihu, I. A., Normala, S., Obid, S., \& Annuar, H. A. (2013). “Measures of Corporate Tax Avoidance: Empirical Evidence From an Emerging Economy". International Journal of Business and Society, vol. 14(3), pp. 412-427.

43. Saputra, M. (2017). "The Influence of Ownership Structures, Financial Distress, and Tax Loss Carry Forward on Tax Avoidance". Journal of Resources Development and Management, vol. 31(2011), pp. 21-31.

44. Saputra Wiko (2015). Kejahatan Keuangan di Sektor Pertambangan.

45. Setiawan, H. (2014). Transfer Pricing Dan Resikonya terhadap Penerimaan Negara.

46. Shil, S. (2014). Positive Accounting Theory And Changes In Accounting Principles : An Exploratory Inquiry Into Bangladeshi Listed Companies. Independent Business Review, vol. 7.

47. Sihaloho, M. J. (2016). Metode Penghindaran Pajak Yang Dilakukan Google.

48. Siregar, R., \& Widyawati, D. (2016). "Pengaruh Karakteristik Perusahaan Terhadap Penghindaran Pajak Pada Perusahaan Manufaktur Di Bei". Jurnal Ilmu \& Riset Akuntansi, vol. 5(2).

49. Sunjono et al. (2013). Aplikasi SPSS untuk Smart Riset (Program IBM SPSS 21.0), retrieved from: http://www.library.usd.ac.id/web/index.php?pilih=search\&p=1\&q=0000126816\&go=Detail (Accessed 01 October 2018).

50. Tanya Y. H. Tang (2016). "Privatization, tunneling, and tax avoidance in Chinese SOEs", Asian Review of Accounting, vol. 24, iss. 3, pp. 274-294, https://doi.org/10.1108/ARA-08-2014-0091.

51. Undang-Undang Republik Indonesia (2016). Undang-Undang Republik Indonesia Nomor 11 Tahun 2016 Tentang Pengampunan Pajak. Retrieved from jakata: Undang Undang Republik Indonesia.

52. Wibowo, T. I. (2015). Ditjen Pajak Berhasil Hentikan Tren Merugi Perusahaan Multinasional, retrieved from: https://kalbar.antaranews.com/berita/336301/ditjen-pajak-berhasil-hentikan-tren-merugi-perusahaan-multinasional (Accessed 01 October 2018).

53. Widyawati, A. A., \& Anggraita, V. (2013). “Pengaruh Konvergensi, Kompleksitas Akuntansi, Dan Probabilitas Kebangkrutan Terhadap Timeliness Dan Manajemen Laba”. Jurnal Akuntansi \& Auditing Indonesia, vol. 17, pp. $135-155$. https://doi.org/10.20885/jaai.vol17.iss2.art5 (Accessed 01 October 2018).

54. Wiguna, I. P. P., \& Jati, I. K. (2017). "Pengaruh Corporate Social Responsibilty, Preferensi Risiko Eksekutif, dan Capital Intensity pada Penghindaran Pajak". E-Jurnal Akuntansi Universitas Udayana, vol. 21, pp. 418-446. 